\section{Scientific Research in the Building Trades}

THE Department of Scientific and Industrial Research is presenting a building research exhibit at the Building Trades Exhibition to be held at Olympia on September 12-26. Most of the work has been carried out at the Building Research Station, Watford; the main exception being the timber portion of the exhibit, for which the Department's Forest Products Research Laboratory at Princes Risborough is responsible. The exhibit covers structural steel, plain and reinforced concrete, cement and cement products, natural stone, limes and plasters, brick and timber; codes of practice for the use of certain of these materials, and aspects of heating and lighting involved in securing comfortable conditions in a building. One of the chief researches is that dealing with steelframe buildings, to which work the British Steel Work Association makes a substantial contribution. This work has already led to savings amounting to as much as twenty per cent in the cost of steelwork in steel-frame buildings. Various aspects of stone decay and the problems involved in the preservation, cleaning and restoration of stone structures are illustrated on the stand; methods of assessing the quality of samples of Portland stone by laboratory tests are also shown. An exhibit on brick and brickmasonry illustrates the procedure used to determine the strength of individual bricks and brick-masonry walls. The section dealing with heating, ventilation and natural lighting includes special instruments devised for comparing different methods of heating, the use of air spaces and metallic surfaces in providing thermal insulation, and the problem of the exclusion of solar heat.

\section{Developing the Electric Grid System}

Two important statements were made in the Times of August 28 concerning the electricity system of Great Britain. An electricity commissioner said that the completion of the grid system and its operation under the Central Electricity Board have solved the problem of bulk supply, but the problem of distribution still remains to be dealt with. The new electricity commissioner, Mr. J. M. Kennedy, was specially appointed to deal with the problem of distributing to the consumer. An official of the Central Electricity Board said that from the technical point of view the grid system is working satisfactorily. It has fully justified itself as an instrument for the efficient production of current and for bulk distribution. Extensive developments are in progress. Two of a series of five water-power plants being erected by a power company are now completed in Kirkcudbrightshire. They will supply millions of units per annum to the Grid for distribution in north-west England and central Scotland. The cost of tapping the Grid and installing a switching and transformer station a year or two ago was more than $£ 20,000$; one was recently completed in Northumberland at a cost of $£ 6,000$. He said that Great Britain is ahead of the world in domestic, commercial and rural electrification. Notwith- standing the great difference in population, there are more electric cookers in use in Great Britain than in the United States of America. In some parts of London, working-class houses of a rateable value of $£ 18$ a year are being fitted with electricity at the rate of 300 a week. The applications of electricity to industry are increasing rapidly.

\section{International Conference on Soil Physics}

A CONFERENCE of the First Commission (Soil Physics) of the International Society of Soil Science was held at the Centre de Recherches Agronomiques, Versailles, on July 2-5, under the presidency of Prof. G. W. Robinson, of Bangor. The programme, arranged in consultation with the French organising committee under the able direction of Dr. A. Demolon, included an official opening by the Minister of Agriculture, three paper-reading sessions with discussions, and a closing session. The communications and discussions covered the subjects of mechanical analysis and soil structure, moisture, colour and temperature. Resolutions embodying suggestions for future work were passed, and a committee was set up in association with the Society of Rheology to draw up a lexicon of terms used in soil physics in the principal European languages. In addition to the business programme, excursions were made to the College and Experiment Station at Grignon, sewage irrigation farms, and other objects of interest in the Seine valley. Entertainments were arranged, including a banquet at Saint Germain. At the conclusion of the Conference, the delegates made a short excursion in Alsace as guests of the Societe Commerciale des Potasses d'Alsace. This excursion included a visit to the State potash mines at Mulhouse, tours in the Vosges and in the Colmar-Strasbourg district, during which palæo-loess and other soil profiles were examined, and a visit to the historic laboratory of Jean Baptiste Boussingault at Liebfrauenberg.

\section{Commercial Timbers of Australia}

SINce the War, most States possessing forests of any importance have, owing to a greater world de. mand or greater competition, been engaged in an endeavour to place their commercial timbers on foreign markets; or, in some cases, in attempts to develop an interior market. Research officers have been studying the properties and uses of the principal commercial timbers of the country concerned with the object of providing purchasers and users with the necessary information in a concise form. Australia has been engaged on research in this direction at the Division of Forest Products. Pamphlet No. 47, "Properties of Australian Timbers (1)" (Government Printer, Melbourne, 1933) by H. E. Dadswell, has recently appeared. This first part of the series deals with the timbers of the genus Eucalyptus which are known as the 'Ash Group'. The real value of this type of research in most countries with forest resources is correctly enunciated by Mr. I. H. Boas, chief of the Division of Products : "Many Commercial timbers in Australia oecur only

(Continued on page 375 .) 